\title{
Jesus, aproximação histórica
}

\author{
PAGOLA, José Antonio: Petrópolis: Editora Vozes, 2010.
}

(651 páginas)

Geraldo Dondici Vieira

A vida de Jesus continua fascinando. Mesmo tendo sido já objeto de tantos estudos, de diferentes abordagens e com variadas perspectivas de análise, a surpreendente e radical guinada cultural e espiritual realizada por Jesus de Nazaré, há mais de dois mil anos, não cessa de nos questionar. $\mathrm{O}$ estudo sobre Jesus tem animado os estudiosos a embrenharem-se por trilhas antigas e novas, a fim de lançar sobre ele holofotes capazes de ajudar homens e mulheres de hoje a reencontrá-lo.

José Antonio Pagola palmilhou essas vias. Mantendo sempre diante dos olhos o texto canônico das fontes cristãs, o Novo Testamento, repassou as principais conquistas da pesquisa histórica e exegética sobre Jesus. O resultado obtido por esse exercício metodológico constitui a grande novidade e a real contribuição do seu livro Jesus - aproximação histórica (Jesús - Aproximacion histórica).

Estamos diante de uma obra rica de preciosas informações. Um panorama inicial, um esquema geral, já aponta para o seu amplo e profundo universo literário e teológico. Vejamos:

1. A apresentação e também o epílogo oferecem ao leitor os instrumentais hermenêuticos que estão nas bases da obra;

2. Os capítulos 1 e 2 fazem um mapa sócio-religioso da Galileia do tempo de Jesus;

3. Nos capítulos 3 a 11, o autor repassa os principais traços da surpreendente figura de Jesus, bem como do movimento estranho que ao redor dele se formou; 
4. Os capítulos 12,13 e 14, cerca de 150 páginas, fazem um levantamento científico e teológico acurado e atual de todos os dados sobre o que teria se passado nos últimos dias de Jesus e sobre sua ressurreição;

5. O capítulo 15 apresenta como a história de Jesus foi relida pela tradição cristã à luz da ressurreição com a finalidade de possibilitar a todos um encontro com Jesus vivo;

6. As notas de pé de página, mais de 1300 , são de grande valor informativo. Dão conta dos resultados das pesquisas modernas e oferecem os dados tomados de fontes bíblicas e extrabíblicas;

7. Os oito preciosos anexos, além de demonstrarem a cientificidade da obra, possibilitam ao leitor posteriores aprofundamentos;

8. As listas bibliográficas após cada capítulo e a bibliografia geral trazem às mãos dos estudiosos da Bíblia uma fonte valiosa.

Diante deste panorama, observamos que a obra Jesus, de J. A. Pagola, pode ser lida a partir de suas várias camadas. Uma primeira leitura, feita a partir da camada narrativa. Ela está tecida de forma econômica, simples, direta e eficaz, com muitas perguntas para provocar a participação do leitor. Uma outra leitura, mais atenta às fontes da pesquisa e à avaliação técnica desses dados, possibilitada pela riqueza e amplitude da notas de rodapé. E ainda uma leitura mais crítica, antepondo as escolhas do autor com questões pontuais abertas pelo confronto da ampla bibliografia.

Os 15 capítulos centrais da obra desenvolvem-se didaticamente mais ou menos da seguinte forma:

- Os dois primeiros capítulos concentram-se no estudo da Galileia e de Nazaré, o povoado de Jesus. Têm a função de contextualizar os acontecimentos da vida de Jesus dentro da realidade política, econômica, cultural, social e religiosa de seu mundo e de seu tempo. Das muitas informações relevantes, merecem atenção: o fenômeno da urbanização da Galileia, o endividamento crescente de suas populações por causa dos pesados impostos e a vida familiar experimentada por Jesus em Nazaré da Galileia.

- Os noves capítulos seguintes $\left(3^{\circ}\right.$ ao $\left.11^{\circ}\right)$ apresentam a Boa Notícia de Jesus: a mensagem de Jesus é dirigida à terra habitada de Israel e não ao deserto; o anúncio da chegada do Reino de Deus e a necessidade que ele seja acolhido; a experiência da compaixão de Deus para com os últimos, levada por Jesus de aldeia em aldeia.

A compaixão do Pai está retratada em muitas parábolas de Jesus (Lc 15,11-32). A atividade terapêutica de Jesus, libertando os últimos das garras da doença e de demônios, faz com que a compaixão de Deus seja visível. Da ação "curativa" de Jesus emanam naturalmente características essenciais de sua vida e missão: a defesa dos últimos e das vítimas; a amiza- 
de profunda com as mulheres, bem como a acolhida às crianças e o ensinamento de sabedoria que exige profeticamente a garantia de vida para todos. Isto é o Reino de Deus: o início da destruição do ódio e da inimizade entre os seus filhos (pág. 314). A oração do Pai Nosso condensa toda a beleza e profundidade da Boa Nova de Jesus (Lc 11,2-4; Mt 6,9-13).

- Os capítulos sobre a paixão, morte e ressurreição de Jesus $\left(12^{\circ}\right.$ ao $\left.14^{\circ}\right)$ repassam as principais respostas dadas pela pesquisa a três perguntas: Por que Jesus morreu? Como Jesus morreu? Como avaliar os relatos da ressurreição? Tomando uma posição de equilíbrio, o autor responde assim:

1. Atuando Jesus como mediador da bênção divina, ele afrontou a principal prerrogativa do Templo. A entrada "antitriunfal" de Jesus em Jerusalém e o ato simbólico de purificar o templo teriam bastado para decretar a execução de Jesus;

2. As fontes antigas concordam que Jesus foi executado numa cruz; que a sentença foi ditada pelo governador romano; que houve uma denúncia feita contra Jesus pelas autoridades judaicas e que ninguém se preocupou em eliminar os seguidores de Jesus;

3. Os relatos da ressurreição de Jesus demonstram que este é o fato decisivo na história para os seguidores de Jesus. A partir dele, a história humana ganha seu autêntico fundamento e abre-se a uma esperança definitiva garantida.

- O último capítulo $\left(15^{\circ}\right)$ mostra como os quatro evangelhos aprofundaram a identidade de Jesus. O desenvolvimento teológico dos "nomes" dados a Jesus (Messias, Sumo Sacerdote, Senhor, Verbo Encarnado, Filho do Homem) realizou os primeiros e decisivos passos da cristologia.

A análise histórica rigorosa sobre Jesus e o esforço de adaptar a sua mensagem ao leitor moderno consistem nos dois principais objetivos do livro. A apresentação do livro procura descrever tecnicamente seus expedientes metodológicos:

1. métodos empregados pela ciência histórico-crítica;

2. investigação criteriosa das fontes literárias disponíveis (critério da dificuldade; da descontinuidade; do testemunho múltiplo; da coerência);

3. atenção às contribuições da arqueologia, da antropologia cultural, da sociologia, da economia, etc.;

4. avaliação de todas as principais obras atuais sobre Jesus;

5. distanciamento das posições radicais de alguns estudos sobre as fontes apócrifas e de certas pesquisas que buscam eliminar a validade da leitura científica de fontes cristãs;

6. critério fundamental de D.G. Dunn: aproximar-se de Jesus estudando sobretudo a lembrança que ele deixou nos seus (pág. 19). 
Promover o diálogo entre os resultados das pesquisas históricas sobre Jesus e as riquezas transmitidas pelas fontes cristãs consistem na grande novidade da obra. $\mathrm{O}$ autor mesmo adverte que, ao lado do método científico histórico-crítico e da releitura criteriosa das fontes, desenvolveria duas atitudes de ordem existencial: a afinidade, a sintonia com a mensagem de Jesus, e a atualidade, o significado da vida de Jesus para o leitor de hoje. Todo este conjunto de instrumentos científicos e projeções comunicativas aplicado, passo a passo, a cada um dos grandes capítulos da vida de Jesus conferem à obra o caráter de permanente diálogo interdisciplinar e de narrativa original de sensibilidade moderna, mas, ao mesmo tempo, fiel às tradições canônicas. Tais procedimentos e seus devidos resultados dão à obra um expressivo sinal de novidade benfazeja.

O imaginário poético de Jesus, especialmente suas parábolas, é tomado como fonte significativa de pesquisa histórica (pág. 145). Exercitando-se amplamente este expediente de releitura das fontes, com resultados satisfatórios, sente-se, no entanto, a necessidade de algum aprofundamento mais técnico-exegético destes textos tomados como referência.

Uma possível oposição feita pelo modo de agir de Jesus à sociedade patriarcal do seu tempo pode levar a conclusões apressadas e sem fundamento. Também tal conclusão carece de um estudo exegético acurado dos textos arrolados, por exemplo, nos relatos de vocação (pág. 336).

Não submissão a César; comunidade sem dominação masculina; experiência de vida na insegurança e cultivo da alegria como valor dominante são, sem dúvida, características da identidade cristã muito apreciadas pelo leitor moderno. Mas será preciso aprofundar, na análise dos textos, de que modo o leitor dos evangelhos percebeu a realidade destes fatos e identificouse com eles.

Por fim, a obra Jesus, de J. A. Pagola, lança-nos o desafio científico de fazer acontecer o diálogo entre as várias ciências e suas diferentes abordagens sobre o tema Jesus. Testemunha ainda, de modo primoroso, a riqueza e a profundidade das fontes literárias cristãs e sua refinada teologia. Pede ao leitor cristão de hoje o trabalho constante de deixar Jesus falar ao nosso mundo e em nosso tempo. As pesquisas modernas e o aprimoramento dos métodos não podem servir para encobrir o que Jesus fez e falou, falsificando sua mensagem aos homens e mulheres de hoje.

Geraldo Dondici Vieira

Doutor em Teologia Bíblica pela FAJE-BH Professor do Departamento de Teologia da PUC-Rio 